\title{
The role of information and communication technologies in improving teaching and learning processes in primary and secondary schools
}

\author{
Albert Sangrà ${ }^{\mathrm{a} *}$ and Mercedes González-Sanmamed ${ }^{\mathrm{b}}$ \\ ${ }^{a}$ eLearn Center, Universitat Oberta de Catalunya, Roc Boronat 117, 08018 Barcelona, Spain; \\ ${ }^{b}$ Universidad de A Coruña, Facultade de Ciencias de la Educación, Campus de Elviña, 15071 \\ A Coruña, Spain
}

(Received 31 January 2010; final version received 30 September 2010)

\begin{abstract}
The purpose of this study is to analyse what is happening at schools regarding the integration and use of information and communication technologies (ICT) and to examine teachers' perceptions about what teaching and learning processes can be improved through the use of ICT. A multiple-case-study research methodology was applied. From a previous exploratory research, four different types of schools were determined. Data show there is a widespread view that ICT in teaching favours several teaching and learning processes. In particular, it shows that the contribution of ICT to the improvement of teaching and learning processes is higher in the schools that have integrated ICT as an innovation factor. To attain this highest level implies that a school not only has to modernise the technological tools, but also has to change the teaching models: the teacher's role, issues regarding classroom organisational, the teaching and learning processes, and the interaction mechanisms.
\end{abstract}

Keywords: school improvement; information and communication technologies; teaching and learning processes; educational innovation; quality

\section{Introduction}

In recent years, several studies and reports have highlighted the opportunities and the potential benefits of information and communication technologies (ICT) for improving the quality of education. ICT is viewed as a "major tool for building knowledge societies" (UNESCO 2003, 1) and, particularly, as a mechanism at the school education level that could provide a way to rethink and redesign the educational systems and processes, thus leading to quality education for all.

Additionally, in Europe, appropriate use of ICT in school education is considered a key factor in improving quality at this educational level. The European Commission is promoting the use of ICT in learning processes through its eLearning Action Plan, one of the aims of which is "to improve the quality of learning by facilitating access to resources and services as well as remote exchange and collaboration" (Commission of the European Communities 2001, 2).

*Corresponding author. Email: asangra@uoc.edu 
This report outlines several aspects to be observed and promoted, such as widespread access to broadband technologies, professional development support policies for teachers, more research into how people teach and learn using ICT, development of new high-quality online content and adaptation of current regulations to make the use of ICT at schools easier, as more recent UNESCO publications also highlight (UNESCO 2008).

The efforts of different governments and administrations have been focusing on providing the schools with good equipment. However, an analysis of the educational uses of ICT in the classroom has been lacking.

This research focuses on the need to develop appropriate strategies to face this new teaching role and, additionally, the students' role when integrating ICT in the teaching and learning processes. The role and the perspective of teachers have become highly relevant, highlighting them as crucial players in this process. Particularly, teachers use technology depending on their perceptions and their trust in the way it can contribute to the teacher and the learning process. Through knowing what they think, we will be closer to understanding what they do or what they might do with technology in their classrooms and in relation to their work.

\section{Media and ICT for education: research perspectives}

A review of research on educational media, and more particularly on the integration of digital media in education, has allowed us to identify several areas of study that have been developed in different periods and under different epistemological, methodological and didactic assumptions. From the beginning, research has been centred on audiovisual media, but given the development of other technologies and, particularly, the inclusion of computers in school classrooms, new studies have been carried out on the impact and effects of the use of these technologies in schools.

Inspired by the classification outlined by Clark and Sugrue (1988) and also in the later revisions made by Area (2005), Cuban (2001), Ringstaff and Kelly (2002), we have presented the following scheme in which we try, firstly, to build up a framework through which we can situate the different issues and concerns linked to most of the research on audiovisual media and computer-based education and, secondly, to situate the research we have carried out:

(a) Studies on the media itself, leading to design analysis and media evaluation, involving software, hardware and even courseware. We could include in this group the analysis of quantitative indicators that describe the situation and use of computers in the educational systems (Euridyce 2001; OECD 2003; Twinning 2002).

(b) Studies on media and learning. This line of research begins in behaviourism and evolves towards cognitive positions in which, from a micro-psychological viewpoint, the interaction of media-subject and the possible modulator effects between them are considered to promote learning. We should highlight in particular those studies in which the impact of intelligent technologies on human reasoning and learning (Salomon, Perkins, and Globerson 1992) and the importance of the social context in cognitive change (Chia and Duthie 1993) are analysed. From this perspective, several models have been developed from which the relationship between media attributes, teaching methods, learning tasks and students' cognitive outcomes were explored. 
Several authors have also presented some meta-analysis of the various research carried out to measure the effect of the use of computers in teaching and learning processes and in academic results (Blok et al. 2002; Kirkpatrick and Cuban 1998; Parr 2000).

(c) The didactic approach and the analysis of media from a teacher's perspective. In recent decades, research into educational media has aimed to solve those problems that media faces in teaching and learning situations, with the objective of outlining proposals to improve curricular implementation and design. Research undertaken in the 'natural' contexts of the school and classroom has shown that the teacher's role is prominent. This research involves several studies from different methodological perspectives, and analyses the following:

- Attitudes, opinions, perception and assessment of teachers' assumptions on the advantages of the use of technologies (Cope and Ward 2002; Windschitl and Salh 2002) Teachers' decisions regarding selection, use and evaluation of educational media (Solmon and Wiederhorn 2000).

- Teachers' initial and continuous training and their training needs and demands in order to better help them integrate technology in teaching and learning (Davis, Preston, and Sahin 2009).

- Organisational issues related to implementation of media and its impact in the contexts where applied (Condie and Munro 2007).

- Institutional issues arising from programme design and development and from projects of implementation and diffusion of a particular medium in a specific context (González-Sanmamed and Pérez-Lorido 2002).

(d) Studies on telematic networks. The emergence of the Internet has opened new educational research perspectives and has incorporated new issues and methodologies. From this perspective, we have identified three major research lines:

- Internet as a learning tool has been categorised into three broad areas: as a tool to develop training activities at schools in the form of a complementary activity, as a way to facilitate personal contact and therefore interaction among people, and as a resource to widen access to content and services (Sangrà 2001).

- Collaborative learning. Despite being an almost traditional approach (Lave 1988; Lave and Wenger 1991), the link between collaborative learning and ICT has revealed stronger possibilities. Some research studies have focused on how students organise themselves to develop collaborative learning in a virtual environment and how this environment should be better designed (Harasim et al. 1995; Guitert et al. 2003).

- Learning virtual communities. Another research line has focused on how ICT can help to build actual learning communities in cyberspace (Powers 1997; Palloff and Pratt 1999; Renninger and Shumar 2002). Research has also examined how these communities could develop into a community of practice (Wenger 1998) and a powerful tool to achieve personal and professional goals, and also how they contribute to new knowledge-building (Landow 1997; Laurillard 2002).

- A further issue that different research studies highlight is how the actors in teaching and learning processes need to change their roles as members of a virtual learning community: students must adopt an active role (Sangrà and González-Sanmamed 2004). 


\section{Technology, learning and educational practice: integration and pedagogical innovation}

When, how and why do computers come to be used in classrooms? What are the factors involved in the processes of technology integration in schools? In what teaching and learning processes are computers used in the classroom? How and under what conditions can these practices generate processes of innovation?

Attempts to answer these questions have resulted in a number of different studies that have identified the uses of technology in education and its role in the educational innovation processes.

As stated in the VI Annual Report on the Development of the Information Society in Spain (AA.VV. 2006), since the 1980s every regional authority has fostered several programmes aiming at integrating ICT into society and, particularly, in education (Plan Avanza 2007). The actions carried out ranged from the development of infrastructures, to the setting up of educational portals and platforms with educational resources for teachers, parents and students, to training programmes for using ICT.

In the international context, there have been a number of significant studies by associations and organisations in which the increasing of equipment and ICT is highlighted, despite very different types and degrees of integration (Anderson 2002; Tondeur, Valcke, and Van Braak 2008), and the level of teachers' use is quite low (Law, Pelgrum, and Plomp 2008; Pelgrum 2001). This points out the need for identifying the variables related to ICT integration in schools (BECTA 2004; Ringstaff and Kelley 2002; Tearle 2003). The conclusions of some of these studies is that ICT integration processes are complex and that internal and external factors play an important role (Davis et al. 2009; Ertmer 2005; Law et al. 2005; Nachmias et al. 2004; Tearle 2003). Amongst the internal factors, characteristics of school organisation and staff are mentioned. Policies regarding ICT, infrastructures, staff training and relationships with the context are pointed out as external factors.

Particularly, one of the main handicaps to develop the educational potential of ICT comes from the traditional culture of schools (Pelgrum 2001; Wilson, Notar, and Yunker 2003; Williams 2005). Previous practice in using computers and positive attitudes towards technology are variables that favour success in teachers' integration of ICT (Drent and Meelissen 2008; Mueller et al. 2008). In addition, research shows that ICT is no generating the expected significant changes (Cuban 2001; Cuban, Kirkpatrick, and Peck 2001; Robertson 2003). On the other hand, it is clear that educational changes addressed through ICT may result in effective changes in student learning (Wong and Li 2008).

In the framework of a wider research project, partially funded by the Spanish Ministry of Science and Technology, leading to observations on the integration of ICT in School Education, an exploratory analysis was developed to identify teachers' perceptions and their impact on how ICT contributed to the development of teaching and learning processes.

The purpose of this research was to analyse what was happening in schools related to the integration and use of ICT, broadening a previous study (Sangrà, Bellot, and Hinojosa 2002). In this article, in particular, we present findings related to two of the specific aims of the project:

- to examine teachers' perceptions on which teaching and learning processes could be improved through the use of ICT, and 
- to outline the involved factors for the effective use of ICT from the point of view that it is a key factor for innovation.

\section{Methodology}

A multiple-case-study research methodology was applied. The school was the unit of sampling used. A procedure for data gathering was developed and a number of tools to collect the necessary information were designed and validated.

Keeping in mind the aim of obtaining information to identify trends and practices on the use of ICT at the school, and considering previous research findings in which characteristics of schools are pointed out as a key issue when integrating technology (Davis, Preston, and Sahin 2009; Ertmer 2005; Law, Chow, and Allan 2005; Nachmias et al. 2004; Tearle 2003), three dimensions were combined to classify the centres: infrastructure, use and innovation.

Infrastructure is understood as the hardware and connectivity systems available in the school centre, and the structural organisation of the teaching spaces linked to ICT. Use is understood as the types of use of ICT being carried out in each school centre (individual, departmental or global). Innovation was understood as the impact of ICT on increasing the quality of education in the school centre, and the degree of involvement of the entire staff in this commitment.

In addition, four school 'levels' were established by combining these three dimensions mentioned above:

(a) Level 1 schools: schools with a limited use of ICT in educational tasks. Connectivity is limited to a computer without having a network. There is a lack of motivation and/or interest from the teachers.

(b) Level 2 schools: schools that have a well-equipped computer classroom. Its use is not intensive and depends on the interest of some teachers. The use of ICT is not outlined in the Development Plan or is still at an embryo stage.

(c) Level 3 schools: schools having one or more very well-equipped computer classrooms. These computers are interconnected and a local area network has been set up. Moreover, there are also some computers in the regular classrooms offering the possibility of being used by the students and teachers during lessons. The use of ICT is partially included in the Development Plan through some departments.

(d) Level 4 schools: schools that have decided ICT is a distinctive element of their educational activities. They have very good equipment and are fully connected to the net. There is someone responsible for solving any maintenance problem and teachers trust him/her. The schools in this category have a Development Plan that originates in strong leadership from their Executive Board.

To determine the sample, a selection of typical-ideal cases (Goetz and LeCompte 1988) with an instrumental purpose (Stake 1995) was chosen. The selection was made considering the four levels of schools established by the research team in a previous exploratory research and the findings of several studies mentioned before on the influence of technology integration at schools.

Categorisation and selection of schools were made from the information provided by system supervisors, coordinators of ICT integration programmes and advisors to teacher support centres. Two schools (one primary, one secondary) for every 
determined level were selected from each region. Some difficulties in this process meant we were not able to recruit the 40 schools intended in the initial study design.

On this basis, schools representing each level were chosen in each region of the study (Galicia, Madrid, Valencia, the Basque Country and Catalonia), as shown in Table 1. The additional characteristics of the selected schools can be observed in Tables 2, 3 and 4.

Data were collected using the following tools: interview with the school's Executive Board, good practice guidelines, and other information resources from the different schools (reports, strategic plans, teaching plans, etc.) and a questionnaire given to school teachers.

All teachers at the participating schools were asked to complete a questionnaire to collect data about their competencies, uses and attitudes related to ICT in education. The specific questionnaire (CUEFORTIC) was drawn up with this objective. It was

Table 1. School distribution by region.

\begin{tabular}{lcc}
\hline Region & $n$ & $\%$ \\
\hline Catalonia & 7 & 20.6 \\
Galicia & 7 & 20.6 \\
Madrid & 6 & 17.6 \\
The Basque Country & 8 & 23.5 \\
Valencia & 6 & 17.6 \\
Total & 35 & 100 \\
\hline
\end{tabular}

Table 2. Geographical distribution of the schools in the sample.

\begin{tabular}{lcc}
\hline Situation & $n$ & $\%$ \\
\hline Rural & 6 & 17.1 \\
Town & 8 & 22.9 \\
Urban & 21 & 60 \\
Total & 35 & 100 \\
\hline
\end{tabular}

Table 3. Ownership distribution of the schools in the sample.

\begin{tabular}{lrc}
\hline Ownership & $n$ & $\%$ \\
\hline Public & 24 & 68.5 \\
Private partially funded & 8 & 22.9 \\
Private & 3 & 8.6 \\
Total & 35 & 100 \\
\hline
\end{tabular}

Table 4. Typology distribution of the schools in the sample.

\begin{tabular}{lrr}
\hline Type of school & $n$ & $\%$ \\
\hline Primary & 18 & 51.5 \\
Secondary & 5 & 14.3 \\
Both & 11 & 31.4 \\
Rural cluster & 1 & 2.8 \\
Total & 35 & 100 \\
\hline
\end{tabular}


divided into five sections: personal data (six items), use of ICT in teaching practice (79 items), attitudes towards ICT (17 items), training experience and training needs (47 items), and school equipment (10 items). Each item was related to a five-point Likert scale: 1 , nothing; 2 , a few; 3 , something; 4, quite enough; and 5, a lot.

From the 1546 teachers working in the 35 schools, a total of 1222 questionnaires have been gathered, representing $78.9 \%$ of the universe of the sample. An analysis of the 1222 answers was carried out with the Statistical Package for Social Sciences. Even though we have data relating to teachers' gender, age and teaching experience, in this paper we will only discuss the main findings.

Approximately two-thirds of the sample were women (63.7\%), which is the usual average found on current teachers' characteristics and strengthens the idea of the feminisation of teaching.

Regarding age, most of the teachers were between 35 and 44 years old (39.1\%). Outside this age group, 25.2\% were between 25 and 34 years old, and $23.9 \%$ were between 45 and 54 years old. Finally, most of the teachers in the sample (34.1\%) had more than 20 years of teaching experience, followed by those with between 13 and 20 teaching years experience $(26.5 \%)$. We should note that this was a highly experienced sample, which we could situate - on the basis of the Life Cycles theory (Huberman 1989) - in a phase of consolidation and professional maturity that can evolve towards two different and opposite trends: to be conservative or innovative.

Regarding the ethical issues, all permissions were requested and anonymity of centres and teachers was respected. Confidential use of information was guaranteed, and it was only used for statistical treatment and for the purposes of the research. There was no conflict of interests due to the fact that schools' decision to participate it was voluntary, as was teachers' participation.

\section{Research questions}

In this article we focus on two research questions: how ICT is contributing to the development of teaching and learning processes; and what, if any, are the differences between the teachers at the different school levels we have categorised.

\section{Question 1: how is ICT contributing to the development of teaching and learning processes?}

As previously pointed out in our review of the literature, one of the main concerns of studies on educational technology has been to identify what uses of ICT are being applied in schools and how teaching and learning processes can be better developed through them. Keeping in mind this perspective, we considered it of interest to inquire into teachers' opinions about the teaching and learning processes we could be encouraged to use when incorporating ICT in teaching and learning.

The teaching and learning processes we have highlighted are based on Bloom's taxonomy (Bloom 1956). Despite the constructivist ideas that have been disseminated and accepted in the Spanish educational area, Bloom's taxonomy is still respected and used, particularly as a referent in educational planning processes and to fix identifiable aims in educational settings. This is so perhaps because many teachers have been trained on this basis, and also because the taxonomy is useful when describing the students' learning levels and domains. 
Knowing teachers' opinion on the contribution of ICT in each of the domains established by Bloom moves us closer to their vision on how technology might be used to reach the educational aims related to each of the categories of Bloom's taxonomy. When asking about these categories, we are investigating the learning aims that the teachers consider might be reached through the use of technology and the kind of strategies that can be developed in the technology-mediated classrooms.

Bloom (1956) classifies educational objectives into three main domains: cognitive, affective and psychomotor. In the cognitive domain are those processes related to knowledge, comprehension, application, analysis, synthesis and evaluation. In the affective domain we find processes related to attention, elaboration of responding patterns, valuing skills and development of organisational schemes. Finally, from the psychomotor domain we selected perception, expression and communication skills.

The average scores from the questionnaires were quite high and were spread evenly across the three domains (see Table 5). Therefore, we can affirm that teachers have a high expectation level with respect to ICT and a positive estimation of its impact on learning: most of the teachers that took part contended that the use of ICT in classrooms benefits some teaching and learning processes.

Teachers have pointed out that using ICT at school helps to improve students' attention $(x=4.09)$ and perception skills $(x=3.97)$. If we consider attention as a basic requirement for learning (Pozo 2000), we could suppose that ICT is facilitating learning because it helps create better learning conditions by raising and promoting students' attention skills. Moreover, increasing perception skills could be favourable to learning because students will be in a better condition to process and translate the stimuli that allow them to build new thinking and action schemes.

The use of ICT also stimulates the creation of responding mechanisms $(x=3.94)$, needed to face learning experiences and the resulting new demands. One of these mechanisms relates to applying what you have learned, and in this respect ICT is also perceived as a help. ICT offers numerous possibilities to manipulate and simulate situations, phenomena, actions, and so on, representing extraordinary educational potential for the application of learning.

Table 5. Influence of ICT in developing teaching and learning processes.

\begin{tabular}{lcc}
\hline Teaching and learning processes & $n$ & Average \\
\hline Knowledge acquisition & 1195 & 3.89 \\
Understanding improvement & 1196 & 3.73 \\
Application of learning & 1191 & 3.91 \\
Strategies of analysis & 1166 & 3.43 \\
Synthesis processes & 1159 & 3.48 \\
Evaluation processes & 1180 & 3.58 \\
Fixing attention & 1191 & 4.09 \\
Response mechanisms & 1168 & 3.94 \\
Evaluation strategies & 1168 & 3.45 \\
Organisational schemes & 1160 & 3.55 \\
Perception skills & 1178 & 3.97 \\
Expression-communication & 1154 & 3.44 \\
Other & 58 & 2.90 \\
\hline
\end{tabular}


We should also highlight the average score obtained in items related to knowledge acquisition $(x=3.89)$ and content understanding improvement $(x=3.73)$. Thus, the potential of ICT to make students' learning content processes easier has been recognised: to remember, define, recognise or identify particular information; to understand and absorb this information, to organise and mentally sort it, to interpret it from the standpoint of their own thinking schemes and to express it in their own words.

Other teaching and learning processes get lower averages, as in the variables related to strategies of analysis $(x=3.43)$, evaluation processes $(x=3.58)$, synthesis processes $(x=3.48)$, strategies for evaluation $(x=3.45)$ and organisational schemes $(x=3.55)$. Expression and communication are the least valued items, perhaps because the teachers considered the use of ICT as being one-way, where students act just as receivers.

It is interesting to observe that some teachers have not yet discovered or understood the possibilities that ICT offers to students as a means of complementing their traditional receiver role with that of a message producer-transmitter (Cuban, Kirkpatrick, and Peck 2001; Drent and Meelissen 2008). Networking, in particular, is based on the communicative opportunities that technological systems are making easier and in promoting positive attitudes towards a collaborative and constructive learning perspective.

Teachers are also less confident using ICT to promote the development of more complex teaching and learning processes, such as strategies of analysis, synthesis, evaluation and organisation. Remarkably, these are very important skills for navigating the net and for taking advantage of the enormous amount of information available. This means that the role of the teacher will be fundamental to contributing to the growth of these skills and for orienting a useful employment of ICT.

Several studies highlighted the crucial role of teachers, their beliefs and practices in determining the level and type of use of technologies in the classroom (Nachmias et al. 2008; Somekh 2008; Webb 2002). Some of these studies contend that ICT use strengthens traditional practices, and they found that it is difficult for teachers to develop innovations by taking advantage of what technology has to offer (Cuban, Kirkpatrick, and Peck 2001), Our findings demonstrate that technology is mainly used to develop low-level teaching and learning processes, suggesting teacher-centred models.

\section{Question 2: are there significant differences between teachers from different school levels?}

In general, we can see that teachers in centres where ICT is considered a key innovation factor (Level 4 schools) have a more homogeneous view of the analysed processes, perhaps because technology has been integrated in a stable way and is not seen as either a novelty or as being deceptive (see Table 6).

Teachers from Level 2 schools get the highest scores, probably because they are in an initial phase of development and their expectations are still quite high. On the other hand, it is quite surprising that the lowest scores come from the Level 3 schoolteachers, those schools labelled as having an intensive use of ICT.

The item in which highest scores coincide independently of the school level is that which acknowledges the role of ICT in promoting attention skills. The second highest score relates to the improvement of perception skills. 
Table 6. Correlation between school levels and the teaching and learning processes facilitated.

\begin{tabular}{|c|c|c|c|c|c|c|c|c|}
\hline \multirow{2}{*}{$\begin{array}{l}\text { Teaching and learning } \\
\text { processes }\end{array}$} & \multicolumn{2}{|c|}{$\begin{array}{l}\text { Level } 1 \\
\text { schools }\end{array}$} & \multicolumn{2}{|c|}{ Level 2 schools } & \multicolumn{2}{|c|}{$\begin{array}{l}\text { Level } 3 \\
\text { schools }\end{array}$} & \multicolumn{2}{|c|}{$\begin{array}{l}\text { Level } 4 \\
\text { schools }\end{array}$} \\
\hline & Average & $\mathrm{SD}$ & Average & SD & Average & SD & Average & SD \\
\hline Knowledge acquisition & 3.73 & 0.94 & 4.05 & 0.73 & 3.68 & 0.85 & 3.88 & 0.81 \\
\hline $\begin{array}{l}\text { Understanding } \\
\text { improvement }\end{array}$ & 3.66 & 0.88 & 3.84 & 0.79 & 3.42 & 0.84 & 3.78 & 0.78 \\
\hline Application of learning & 3.91 & 0.90 & 3.96 & 0.68 & 3.74 & 0.70 & 3.94 & 0.83 \\
\hline Strategies of analysis & 3.41 & 0.89 & 3.52 & 0.74 & 3.37 & 0.77 & 3.36 & 1.02 \\
\hline Synthesis processes & 3.41 & 0.91 & 3.54 & 0.70 & 3.33 & 0.76 & 3.55 & 0.94 \\
\hline Evaluation processes & 3.56 & 0.91 & 3.58 & 0.83 & 3.58 & 0.71 & 3.60 & 1.01 \\
\hline Fixing attention & 4.04 & 0.84 & 4.08 & 0.83 & 4.09 & 0.80 & 4.14 & 0.86 \\
\hline Response mechanisms & 3.48 & 0.92 & 3.84 & 0.76 & 4.05 & 0.43 & 3.73 & 0.92 \\
\hline Evaluation Strategies & 3.38 & 0.91 & 3.52 & 0.85 & 3.46 & 0.64 & 3.37 & 0.99 \\
\hline Organisational schemes & 3.52 & 0.96 & 3.57 & 0.83 & 3.40 & 0.73 & 3.61 & 1.08 \\
\hline Perception skills & 3.95 & 0.85 & 4.05 & 0.74 & 3.95 & 0.64 & 3.89 & 0.87 \\
\hline Expression-communication & 3.36 & 0.98 & 3.47 & 1.11 & 3.59 & 0.98 & 3.35 & 1.17 \\
\hline
\end{tabular}

Note: SD, standard deviation.

Perceptions are quite varied with respect to the items that get the lowest average scores, except for the item referring to expression and communication skills, which was rated lowest by most of the teachers.

Previous studies show that the success of innovative practices of technology use in schools is strongly related to the particular characteristics of each school. Infrastructure, equipment, a favourable school culture and the support from staff make the development of innovative practices with ICT easier (Pelgrum 2001; Williams 2005; Wilson, Notar, and Yunker 2003).

In addition, as Voogt (2008) stated, effective integration of ICT implies the reviewing of educational aims and their curricular content. Domain analysis developed in this research could become a reference to re-consider what we would like our students learn and how to use technology to help ourselves to this end.

\section{Conclusions}

From the teachers' answers, we can conclude there is a mainstream opinion that sees using ICT in teaching as favouring several processes related to teaching and learning - in particular, those involving attention, perception, responding mechanisms, application of learning and understanding. Moreover, those related to information transmission and knowledge facilitation are well thought of. However, some of the proposed processes were more poorly valued: interaction processes and expression and communication skills were not held in high regard by the teachers, probably because they have considered ICT as being generally used in a one-way mode.

On the other hand, there seems to be a relationship between teachers' perceptions and the three dimensions (equipment, use and innovation) of our analysis. 
Teachers in Level 4 schools have a more favourable view concerning the processes that ICT makes easier, probably because they use them in a more general and systematic way and, for this reason, they have developed the needed skills to take a better advantage of them. In this sense, it should be taken into consideration that improvement in the learning outcomes are usually linked to an innovative educational use of technologies (Balanskat, Blamire, and Kefala 2006; Zhao et al. 2002).

Finally, the teachers develop an appropriate and trusting atmosphere in the schools that help them to increase the use of ICT. They are involved in a global project that takes into account aspects such as continuous training and motivation and they feel the schools have strong leadership. We can conclude that the kind of use of ICT is a key factor for innovation, teaching and improvement of learning processes. Designing a plan for ICT integration in which you get the participation of the whole teaching staff of a school will give us the opportunity to reflect and analyse why and with which aim ICT will be used, and this will contribute to its potential as an innovative element of the curriculum (Somekh 2008).

\section{Implications for further research and teachers' training}

The four school levels considered in this study represent a continuum in which different phases can be identified: from the level of infrastructure and equipment available, to the integration of ICT as a resource and, finally, its consideration as a strategic element for the innovation and the improvement of teaching and learning processes. To get to Level 4 implies that a school not only has to modernise the technological tools, but also has to change the teaching models: the teacher's role, issues regarding classroom organisation, the teaching and learning processes, the interaction mechanisms, and so forth.

Some conditions need to be in place to allow most of the schools to move forward along the lines of this model:

- The consideration of ICT as a tool that can contribute to continuous educational innovation in the centres should be introduced in the school strategic plans and, even more, in each year's teaching plan. The cases studied in which this was so achieved better outcomes. Further research should focus on the need for a new and different form of classroom organisation when integrating ICT, where staff roles and equipment should be organised differently.

- The teaching staff has a fundamental role in determining what to teach and how to teach it (and what the students are going to learn) using ICT. It is therefore extremely important that they make their beliefs explicit and take them into account when designing teaching processes, in order to better observe and understand innovative uses of technology for high educational level purposes (Cox 2008). These issues will have to be considered when drawing up training proposals, developing them in order to enable teachers and schools to integrate ICT appropriately in the teaching and learning processes.

\section{References}

AA.VV. 2006. Informe España 2006. Informe anual sobre el desarrollo de la sociedad de la información en España. Madrid: Fundación France Telecom España. 
Anderson, R. 2002. Guest editorial: International studies on innovative uses of ICT in schools. Journal of Computer Assisted Learning 18: 381-6.

Area, M. 2005. Tecnologías de la información y comunicación en el sistema escolar. Una revisión de las líneas de investigación. Revista Electrónica de Investigación y Evaluación Educativa 11, no. 1: 3-25.

Balanskat, A., R. Blamire, and S. Kefala. 2006. The ICT impact report. A review of studies of ICT impact on schools in Europe. http://insight.eun.org/shared/data/pdf/impact_study.pdf.

BECTA. 2004. A review of the research literature on barriers to the uptake of ICT by teachers. Coventry: BECTA. http://www.becta.org.uk.

Blok, H., R. Oostdam, M. Otter, and M. Overmaat. 2002. Computer-assisted instruction in support of beginning reading instruction: A review. Review of Educational Research 72, no. 1: 101-30.

Bloom, B.S., ed. 1956. Taxonomy of educational objectives: The classification of educational goals: Handbook I, cognitive domain. New York: Longmans Green.

Chia, J., and B. Duthie. 1993. Primary children and computer-based art work. Their learning strategies and context. Art Education 46, no. 6: 23-35.

Clark, R.E., and B.M. Sugrue. 1988. Research on instructional media 1978-1988. In Educational media yearbook, ed. D. Ely, 19-36. Littletown, CO: Libraries Unlimited.

Commission of the European Communities. 2001. The eLearning action plan. Designing tomorrow's education. Brussels: Directorate General for Education and Culture.

Condie, R., and R. Munro. 2007. The impact of ICT in schools - A landscape review. Report 01/DD06-07/145/PC/2k. Coventry: BECTA. http://www.becta.org.uk/publications.

Cope, C.H., and P. Ward. 2002. Integrating learning technology into classrooms: The importance of teachers' perceptions. Educational Technology \& Society 5, no. 1: 67-74.

Cox, M.J. 2008. Researching IT in education. In International handbook of information technology in primary and secondary education, ed. J. Voogt and G. Knezek, 965-81. Berlin: Springer.

Cuban, L. 2001. Oversold and underused: Computers in the classroom. Cambridge, MA: Harvard University Press.

Cuban, L., H. Kirkpatrick, and C. Peck. 2001. High access and low use of technologies in high school classrooms: Explaining an apparent paradox. American Educational Research Journal 38, no. 4: 813-34.

Davis, N., C. Preston, and I. Sahin. 2009. ICT teacher training: Evidence for multinivel evaluation from a national initiative. British Journal of Educational Technology 40, no. 1: 135-48.

Drent, M., and M. Meelissen. 2008. Which factors obstruct or stimulate teacher educators to use ICT innovatively? Computers \& Education 51: 187-99.

Ertmer, P. 2005. Teacher pedagogical beliefs: The final frontier in our quest for technology integration? Educational Development Research and Development 53: 25-39.

Eurydice. 2001. Basic indicators on the incorporation of ITC into European Education Systems: Annual Report 2000-01. Technical report. Brussels: Eurydice.

Goetz, J.P., and M.D. LeCompte. 1988. Etnografía y diseño cualitativo en investigación educativa. Madrid: Morata.

González-Sanmamed, M., and M. Pérez-Lorido. 2002. Virtual campuses in conventional universities: Difficulties to be overcome. Paper presented at the XI EDEN International Conference, June, in Granada.

Guitert, M., F. Giménez, T. Lloret, et al. 2003. El procés de treball i d'aprenentatge en equip en un entorn virtual a partir de l'anàlisi d'experiències de la UOC. Documents de projecte DO03-001. IN3-UOC. http://www.uoc.edu/in3/dt/20299/index.html.

Harasim, L., R.S. Hiltz, L. Teles, and M. Turoff. 1995. Learning networks. A field guide to teaching and learning online. Cambridge, MA: The MIT Press.

Huberman, M. 1989. La vie des enseignants. Evolution et bilan d'une profession. Paris: Delachaux et Niestle.

Kirkpatrick, H., and L. Cuban. 1998. Computers make kids smarter - Right? Technos Quarterly 7, no. 2. http://www.ait.net/technos/tq_07/2cuban.php.

Landow, G.P. 1997. Hypertext 2.0: The convergence of contemporary critical theory and technology. Baltimore, MD: The Johns Hopkins University Press.

Laurillard, D. 2002. Rethinking university teaching. A conversational framework for the effective use of learning technologies. 2nd ed. London: RoutledgeFalmer. 
Lave, J. 1988. Cognition in practice. Cambridge: Cambridge University Press.

Lave, J., and E. Wenger. 1991. Situated learning. Cambridge: Cambridge University Press.

Law, N., A. Chow, and H.K.Y. Allan. 2005. Methodological approaches to comparing pedagogical innovations using technology. Education and Information Technologies 10, nos 1/ 2: $5-18$.

Law, N., W.J. Pelgrum, and T. Plomp, eds. 2008. Pedagogy and ICT use in schools around the world: Findings from the IEA SITES 2006 study. Hong Kong: CERC-Springer.

Mueller, J., E. Wood, T. Wiloughby, C. Ross, and J. Specht. 2008. Identifying discriminating variables between teachers who fully integrate computers and teachers with limited integration. Computers \& Education 51, no. 4: 1523-37.

Nachmias, R., D. Mioduser, A. Cohen, D. Tubin, and A. Forkosh-Baruch. 2004. Factors involved in the implementation of pedagogical innovations using technology. Education and Information Technologies 9, no. 3: 291-308.

OECD. 2003. Education at a glance. Paris: Organisation for Economic Cooperation and Development.

Pallof, R.M., and K. Pratt. 1999. Building learning communities in cyberspace. San Francisco: Jossey-Bass.

Parr, J. 2000. A review of the literature on computer-assisted learning, particularly integrated learning systems, and outcomes with respect to literacy and numeracy. Wellington, New Zealand: Ministry of Education.

Pelgrum, W.J. 2001. Obstacles to the integration of ICT in education: Results from a worldwide educational assessment. Computers \& Education 37: 163-87.

Plan Avanza. 2007. Las tecnologías de la información y comunicación en la educación. Informe sobre laimplantación y el uso de las TIC en los centros docentes de educación primaria y secundaria (curso 2005-2006). Madrid: Ministerio de Industria, Comercio y Turismo.

Powers, M. 1997. How to program a virtual community. New York: Ziff-Davis Press.

Pozo, I. 2000. Aprendices y maestros. La nueva cultura del aprendizaje. $2^{\mathrm{a}}$ reimpresión. Madrid: Alianza.

Renninger, K.A., and W. Shumar, eds. 2002. Building virtual communities. Cambridge: Cambridge University Press

Ringstaff, C., and L. Kelley. 2002. The learning return on our educational technology investment. A review of findings from research. San Francisco, CA: WestEd RTEC.

Robertson, J.W. 2003. Stepping out of the box: Rethinking the failure of ICT to transform schools. Journal of Educational Change 4: 323-44.

Salomon, G., D.N. Perkins, and T. Globerson. 1992. Coparticipando en el conocimiento: La ampliación de la inteligencia humana con las tecnologías inteligentes. Comunicación, Lenguaje y Educación 13: 6-22.

Sangrà, A. 2001. Present and future use of technologies in education. Keynote speech at the IV EDEN Open Classroom Conference, November, in Barcelona.

Sangrà, A., A. Bellot, and J. Hinojosa. 2000. 1r. Informe Astrolabi sobre la implantació i l'ús de les Tecnologies de la informació i la comunicació a l'ensenyament no universitari. Barcelona: UOC.

Sangrà, A., and M. González Sanmamed. 2004. La transformación de las universidades a través de las TIC: Discursos y prácticas. Barcelona: Ediuoc.

Solmon, L.C., and J.A. Wiederhorn. 2000. Progress of technology in the school: 1999. Report on 27 states. Santa Monica, CA: Milken Family Foundation.

Somekh, B. 2008. Factors affecting teachers' pedagogical adoption of ICT. In International handbook of information technology in primary and secondary education, ed. J. Voogt and G. Knezek, 449-60. New York: Springer.

Stake, R. 1995. The art of case study research. London: Sage.

Tearle, P. 2003. ICT implementation: What makes the difference? British Journal of Educational Technology 34, no. 5: 567-83.

Tondeur, J., M. Valcke, and J. Van Braak. 2008. A multidimensional approach to determinants of computer use in primary education: Teacher and school characteristics. Journal of Computer Assisted Learning 24, no. 6: 494-506.

Twining, P. 2002. ICT in schools estimating the level of investment. Report 02.01, meD8. http://www.meD8.info/docs/pubs.htm. 
UNESCO. 2003. Communiqué of the ministerial roundtable on 'Towards Knowledge Societies'. Paris: UNESCO.

UNESCO. 2008. ICT competency standards for teachers: Competency standards modules. Paris: UNESCO.

Voogt, J. 2008. IT and curriculum processes: Dilemmas and challenges. In International handbook of information technology in primary and secondary education, ed. J. Voogt and G. Knezek. New York: Springer.

Webb, M.E. 2002. Pedagogical reasoning: Issues and solutions for the teaching and learning of ICT in secondary schools. Education and Information Technologies 7, no. 3: 237-55.

Wenger, E. 1998. Communities of practice: Learning, meaning and identity. Cambridge: Cambridge University Press.

Williams, P. 2005. Lessons from the future: ICT scenarios and the education of teachers. Journal of Education for Teaching 31: 319-39.

Wilson, J.D., Ch.C. Notar, and B. Yunker. 2003. Elementary in-service teacher's use of computers in the elementary classroom. Journal of Instructional Psychology 30, no. 4: 256-63. http://www.findarticles.com/p/articles/mi_m0FCG/is_4_30/ai_112686159.

Windschitl, M., and K. Sahl. 2002. Tracing teachers' use of technology in a laptop computer school: The interplay of teacher beliefs, social dynamics, and institutional culture. American Educational Research Journal 39, no. 1: 165-205.

Wong, E.M.L., and S.C. Li. 2008. Framing ICT implementation in a context of educational change: A multilevel analysis. School Effectiveness \& School Improvement 19, no. 1: 99-120.

Zhao, Y., K. Pugh, S. Sheldon, and J. Byers. 2002. Conditions for classroom technology innovations. Teachers College Record 104, no. 3: 482-515. 